\title{
Use of Gamification Applications in Science Education
}

\author{
https://doi.org/10.3991/ijet.v14i01.8894 \\ Cigdem Hursen $\left({ }^{\bowtie}\right)$, Cizem Bas \\ Near East University, Nicosia, Cyprus \\ cigdem.hursen@neu.edu.tr
}

\begin{abstract}
In this research, the impact of gamification applications in science education on the science learning motivation of students has been determined and the opinions of students and parents on applications have been discussed. A total of 16 students and their parents participated in the study. The research was conducted on 4th grade primary students and employed a mixed method consisting of both qualitative and quantitative elements. The motivation of students for learning science was obtained through quantitative data, whereas the opinions of students and parents on the usage of gamification applications were gathered through qualitative data. In the study, it was found that applications in science education created a positive impact on the learning motivation of students for science. Additionally, the research results also displayed that students and parents have positive opinions on the usage of gamification in science education.
\end{abstract}

Keywords-ClassDojo, Gamification, Motivation, Parents, Primary school, Student

\section{Introduction}

In information societies, various needs are arising in the field of education similar to all fields, while researchers turn to new areas that will meet these needs. Traditional teaching applications remain insufficient today and it is emphasised that students should be responsible for their own learning processes, while teachers should serve as guides for the students [1]. Elmas and Geban [2] claim that, particularly with the rapid developments in technology, changes have occurred in the roles of students and teachers, which were followed by the physical changes in classrooms and schools. Nemorin [3] mentions that web technologies are influential factors in the experiences of students and states that the interaction in on-line and off-line media that offer modern education environments create considerable change in students. Online platforms in education make the feelings of students deeper and play a key role in changing their values, beliefs and behaviours [3]. The constant development of technology makes the integration of technology with education compulsory and education systems face the constant need for change and improvement. This change, in turn, allows for the emergence of new approaches towards learning and teaching [4]. Osipov, Volinsky and Grishin [5] mention gamification in education; while Hamari and Koivistoa [6] claim that gamification is 
one of the most popular modern developments, as the importance of technology for supporting and motivating learners in useful behaviours increases.

Gamification is defined as an education platform, which aims to internalize the external motivations of learners, provides feedback, and rewards [7]. It is described as a new trend, which is aimed at increasing the interest, participation, motivation and loyalty of learners [8]. It is stated that the main discussions about gamification started around the end of $2010[9,10]$. In recent years, the popularity of gamification increased in several areas, such as business, marketing, corporate management, finance, health, education, news and entertainment media; one of the basic purposes of gamification is to apply game design elements in real-world contexts and to increase the motivation and performance of learners [10,11, 12,13]. Gökkaya [7] explains that game design elements are particularly used with the purpose of increasing effectiveness in reaching targets. Dicheva et al. [11] assert that traditional education was perceived by most students as ineffective and boring and explain that gamification reinforced not only knowledge but such skills as problem solving, cooperation and communication. Nedergård [12] emphasises that various game elements could be added to gamification, whereas Seixas, Gomes and Filho [14] state that studies try to determine why games are so attractive to students. Kapp [9] emphasises that for the last 40 years, game research has focused on displaying evidence-based results on when, why and how games could be used in classes.

In addition to the scope of games, it is stated that game design elements and game mechanisms of gamification are used with the purpose of attracting the attention of learners and solving problems [15]. Al-Azawi, Al-Faliti and Al-Blushi [16] claim that games could make the concept of learning more fun for learners and provide a platform for creative thinking; furthermore, they act as a motivational factor for learning. Researchers have displayed the differences between game-based learning and gamification and emphasized that gamification transforms the learning process into a game as a whole, whereas game-based learning uses games as part of the learning process. In gamification, the entire learning process becomes a game with the aim of motivating and interacting students through game mechanics and game elements [16]. Having been integrated with educative applications and processes, gamification includes badges, leader boards, progress bars and meters, points and other earned rewards [15]. Lister [17] states that widely used game elements such as badges and boards could motivate students. Moreover, Çağlar and Kocadere [18] state that despite the scarcity of research studies with positive results and the controversy surrounding it's encouraging impact on individuals in terms of competition, studies have displayed that gamification has such advantages as increasing motivation, ensuring dedication to the learning environment and creating an enjoyable learning environment. Additionally, it is stressed that gamification reinforces learning at school [13].

The purpose of gamification is to make the learning process more attractive for learners and to ensure that they gain different learning experiences through a learning environment that is numerous fun activities [19]. In addition, Güler and Güler [19] state that in learning designs employing gamification, the concept of motivation is an important element. Motivation is defined as one of the most important sources of power, which determines the direction, strength, determination of student behaviours at school and 
the speed of reaching purposes in education environments [20]. It also improves creativity by affecting the usage of knowledge, and the conceptual and technical skills of learners [21]. Moreover, it is explained as one of the factors that creates interest and anxiety in students and ensures that they become constructive, creative and efficient individuals by encouraging them to actively participate in classes [22]. Çolak and Cirık [23], on the other hand, claim that one of the major problems faced by students is a lack of motivation for participating in academic activities, which is among the most challenging topics for educationists. Mentioning different motivation types, Ryan and Deci [24] aimed to review the differences between external and internal motivation and summarized the functional differences between these two types of motivations. Reiss [25] defined internal motivation as the individual "doing something for himself", whereas external motivation is described as "individuals seeking to make others happy or an instrumental purpose". In this context, it is believed that it is essential that students have internal motivation during the learning process. In their study, Hong and Masood [26] stated that gamification has a higher potential for ensuring class participation compared to traditional teaching methods and concluded that gamification was more effective on the internal motivation levels of students for learning compared to traditional teaching methods. However, in their study on the impact of gamification in science teaching on external and internal motivation, Erdoğdu and Karataş [27] concluded that using badges in particular increased the external motivations of students, whereas it did not affect their internal motivation. Sánchez-Martín, Cañada-Cañada and Dávila-Acedo [28] expressed that gamification is a modern technique in science education, which requires that the student participates in an entertaining structure while learning. Mekler, Brühlmann, Opwis and Tuch [29], on the other hand, explained that studies included discussions on whether gamification elements affected the motivation of learners and stated that more research is needed to determine the impact of game elements such as points, levels and leader boards on internal motivation. Similarly, Nedergård [12] displayed in his study that more advanced research on the discussion of internal motivation in gamification is required. Sanmugam et al. [30] mentioned that exploring the impact of gamification elements on students is essential. In this context, it is believed that more research is needed to determine the impact of gamification applications in science education on the motivation of students. Additionally, as a result of the literature search conducted, it was found there is an insufficient number of studies on gamification applications in science education. In this context, effort is paid to identify the impact of gamification applications used in science education on the motivation of students for learning science. Moreover, it is believed that parents are as important as teachers in increasing the motivation of students and, in this direction, attention was paid to include parents in the study as well. In this context, it was aimed to identify the opinions of parents on gamification applications in this study. Answers were sought to the following questions in order to reach the purposes of the study:

- Is there any significant difference between the pre-test and post-test scores on the motivations of 4th grade primary students on learning science?

- What are the opinions of 4th grade primary students on the usage of gamification applications in science education? 
- What are the opinions of parents on the usage of gamification applications in science education, before and after the application?

\section{Method}

This study was designed with a mixed method consisting of both quantitative and qualitative elements. The quantitative data needed for determining the motivation of students for learning science were obtained with a "motivation scale for learning science", while the qualitative data based on student and parent opinions on the usage of gamification in science education were collected through an "interview form".

\subsection{Research participants}

The research was conducted on 16 students studying at primary schools under Ministry of National Education of Northern Cyprus as well as their parents. In determining the schools where the application would be realised, the voluntariness and willingness of school managers, students and parents in relation to the study were taken into consideration with the purpose of obtaining reliable information from research data. Particularly as a result of the preliminary interviews held with school managers, the research was conducted in one of the volunteering primary schools. In the determined school, all the 4th grade students taking the science education class $(n=16)$ volunteered for the study. In total, $9(52.6 \%)$ of the students were girls and 7 (43.8\%) of them were boys. All of the students were 10 years old. Additionally, 12 (75\%) mothers and 4 (25\%) fathers participated in the study. In terms of age, $6(37.5)$ of the parents were between 30 and 35 years old, whereas $10(62.5 \%)$ were between 36 and 40 years old.

\subsection{Research design and procedures}

In this research, the opinions of students and parents on the usage of gamification applications in science education were studied and the impact of gamification applications on the science learning of students was explored. Researchers interviewed the manager of the school where the application would be conducted and provided information on the study. After this process, they invited the parents of the 4th grade students on a day agreed with school manager and conducted a 35-minute seminar on the research. All parents $(\mathrm{n}=16)$ volunteered to participate in the study. In addition, written permission was received from 16 parents who allowed their children to participate in the study.

The research used a single group pre-test - post-test experimental design and was conducted on 4th grade science education. The design of the research is shown in Figure 1. The "Motivation scale for learning science" was used in order to determine the impact of science education supported by gamification applications on the science learning motivation of students, whereas "interview forms" were used in order to explore the opinions of parents and students on gamification applications. 
Motivation scale for learning science: In this study where gamification applications are employed, effort has been paid to determine the impact of activities directed towards science education on the motivation of students for learning science. In the study, the "Motivation scale for learning science", developed by Dede and Yaman [31] in 2008, was employed. The scale consists of 23 expressions and 5 sub-dimensions: "motivation for doing research (37-17-21-25-6-29)", "motivation for performance (1224-14-18-30)", "motivation for communication (26-27-31-38-35)", "motivation for cooperative work (23-39-34-22)", and "motivation for participation (20-32-11)". The scale consists of both positive and negative expressions is in a 5 Likert type $(1=$ definitely disagree; $5=$ definitely agree). Dede and Yaman [31] stated that the scores in the scale were between 1.00 and 5.00 and, as the scores obtained from the scale approached 5.00 , the motivation levels of students were high, whereas scores close to 1.00 showed low motivation. In this context, it was interpreted that as the scores obtained from this research approached 5, motivations on science learning increased, whereas scores closer to 1.00 showed low motivation.

Interview form on the usage of Gamification applications in science education: In order to determine the opinions of 4th grade students taking a science education class supported with gamification applications, a semi-structured interview form prepared by researchers was used. The interview form, which was prepared with the purpose of evaluating the opinions of students on the application, consists of questions aimed at determining the effectiveness and limitations of gamification applications. Attention was paid to ensure that the interview form prepared for students was suitable for 4th grade primary students and therefore, opinions were sought from experts. In addition, a semi-structured interview form was prepared in order to determine the opinions of parents on gamification applications before and after the application. The semi-structured interview form prepared for parents was aimed at identifying the awareness, emotions and opinions of parents on gamification and the ClassDojo applications. Interview questions prepared for both students and parents were prepared based on the related literature. In particular, in order to provide a basis for the structural validity of the questions in the interview forms, the opinions of educationists $(n=6)$ and primary school teachers $(\mathrm{n}=7)$ were also obtained. Interview forms on the usage of gamification applications in science education were prepared separately for students and parents so that they could serve the intended purpose.

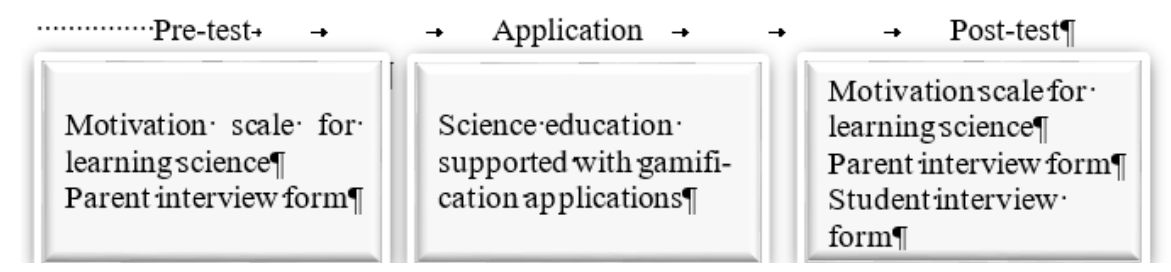

Fig. 1. Design of the research 


\subsection{Application}

Before the application, a meeting was held with the parents of the 4th grade students where the research would be conducted and information on the research was given. Additionally, written permission was obtained from the parents regarding the participation of their children in the study. Attention was paid to ensure that the students and parents who would participate in the study had Internet access, smartphones or tablets. The "Motivation scale for learning science" (pre-test) was applied to the 4th grade students in the first week of the application, while face-to-face interviews were held with the parents $(\mathrm{n}=16)$. In the semi-structured interview form, which was prepared for the parents, the purpose was to determine the emotions and opinions of parents on the participation of their children in an application, which would be different from traditional methods. In addition, an attempt was made through the face-to-face interviews held with parents before the application to determine whether they were knowledgeable about applications such as gamification.

In the application, which continued for 12 weeks and 36 hours in total, the content on science education was conducted based on the curriculum of the science class of 4th grade primary school students. The students were taught such chapters as "let us solve the puzzle of our body" and "microscopic living things and our environment". Activities on science education were performed with the ClassDojo application, which is a gamified class management method. The fundamental reason for preferring the ClassDojo application in the study was that it allows the teacher to share the behaviours displayed by students in the classroom with parents. In addition, the fact that ClassDojo was a free-of-charge application with language options was seen as particular benefit. The language option in the ClassDojo application allowed the students to easily participate in activities in their native languages. In order to ensure reliability, the application was realised by only one of the researchers. The researcher who conducted the application participated in the classes of the 4th grade primary students as their science teacher for 12 weeks. The researcher first registered to the ClassDojo application as a member and created a virtual class. The virtual class was named by the researcher as "Laleler". The students who would participate in the application were also registered by the researcher in the ClassDojo class. After forming the class, the researcher projected ClassDojo application to the smart board and introduced it to the students $(\mathrm{n}=16)$. In addition, she guided the students in registering in the ClassDojo application as a member. Each student who participated in the application chose his/her own avatar in the ClassDojo application. The researcher sent invitations to join the ClassDojo application to both students and their parents. Parents registered in the ClassDojo application with the code that was sent by the researcher. In this context, parents were included in the learning environment and communication between the teacher, parents and students was established. The researcher aimed to bring together the parents and students by using the ClassDojo application and sharing photographs, videos and messages throughout the school day in order to work with parents and students as a team, and to share classroom experiences.

The researcher added both positive and negative student behaviours to the ClassDojo application and scored the behaviours of the students during the application. The aim 
here was to give negative scores to the students' skills that require improvement so as to correct mistaken and incomplete behaviours. During the class, s positive behaviours of students such as "problem solving, helping others, being participatory etc." were rewarded with badges so that that the students would make the effort to gain more positive badges and correct their mistaken behaviours. At the end of each chapter, the scoreboards received by students were shared with the class. Moreover, the students had the opportunity to evaluate their own performances based on the scores and badges they had earned. In addition, besides giving scores to student behaviours, photographs were taken during the activities and classes throughout the day and classroom stories were formed, which were shared with parents, who provided their own interpretations on the shared photographs and expressed their opinions. Students also performed cooperative learning activities throughout the application. For cooperative learning activities, 4 different teams of 4 students each were formed (see Figure 2). In these heterogeneous teams, students gave names to their teams as well. In addition, students were given the freedom to name their own teams. The names chosen by students were "süper dörtlü”, "doğa grubu”, "korocular”, and "yaratıcı çocuklar". In the cooperative learning teams, students conducted studies around a shared goal, such as resolving an issue related to natural sciences, performing given tasks and solving a problem. Tasks were chosen in accordance with the levels of students with the aim of increasing their selfconfidence levels. Teammates who were responsible for each other's' learning assumed individual responsibilities, provided feedback about their studies and motivated each other. The researcher, on the other hand, assumed the role of a guide and helped the teammates to solve the problems they encountered. Teams completed homework at the end of each class with the purpose of reinforcing the covered topics and conducted projects at the end of each chapter. Teams that successfully completed the tasks given at the end of the activities were awarded with badges. By using a common iPad in the classroom, students uploaded the pictures and videos of their works on the ClassDojo application and performed discussions in the classes. In the application where learning by doing and living was conducted, observations in natural environment were made, particularly in the "microscopic living things and our environment" chapter and the children had the opportunity to discuss the living things whose photographs they had taken in the class. In the application where such techniques as brainstorming were used, the purpose was to develop the creativity of the students. In addition, with the ClassDojo application, every student created a portfolio in which he/she could exhibit the class activities. Screen captures of science education activities are given in Figures 3 to 7.

Throughout the application, parents had the opportunity to follow the activities that children performed in the class. In addition, the researcher conveyed all announcements to the parents via the ClassDojo application. Feedback regarding the development of children was also given through this application. The success status and homework performance of students were monitored with the ClassDojo application. Student behaviours were analysed for each individual and the class as a whole and evaluations were subsequently made. The researcher provided feedback to the students in regard to the evaluation results and gave awards to the teams that obtained the highest score in the group studies. Again, the students who received the highest scores were given the right to change their avatars in order to increase the motivation of students towards the class. 
At the end of the 12 weeks, the "motivation scale for learning science" was applied as a post-test in order to determine whether there was an increase in student motivations for learning science. Additionally, face-to-face interviews were held at the end of the application with the purpose of determining the opinions of students and parents on science education that employed gamification applications. The interviews lasted between 20 and 25 minutes.

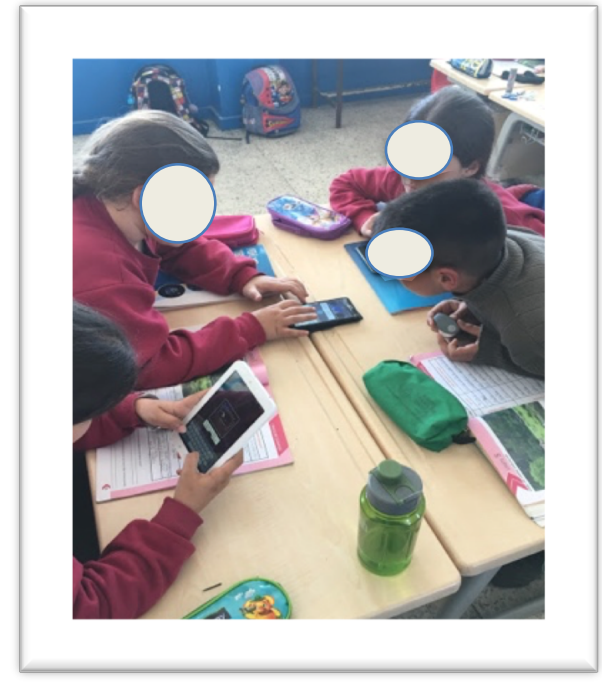

Fig. 2. Cooperative learning team

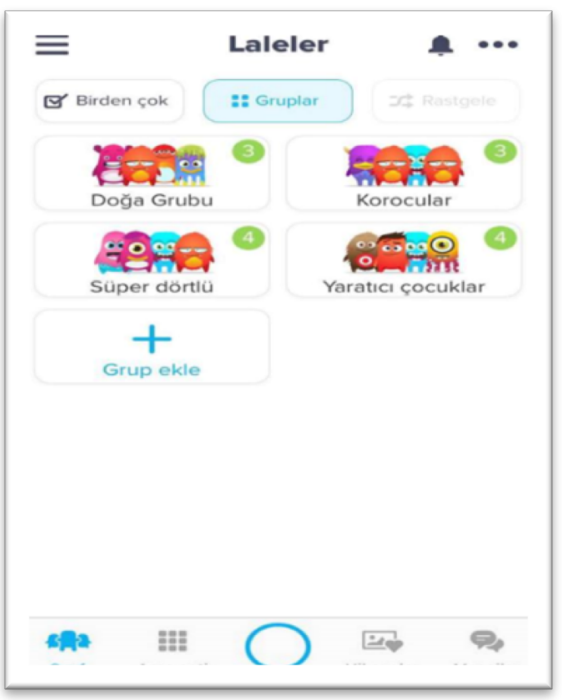

Fig. 4. Score distribution of teams

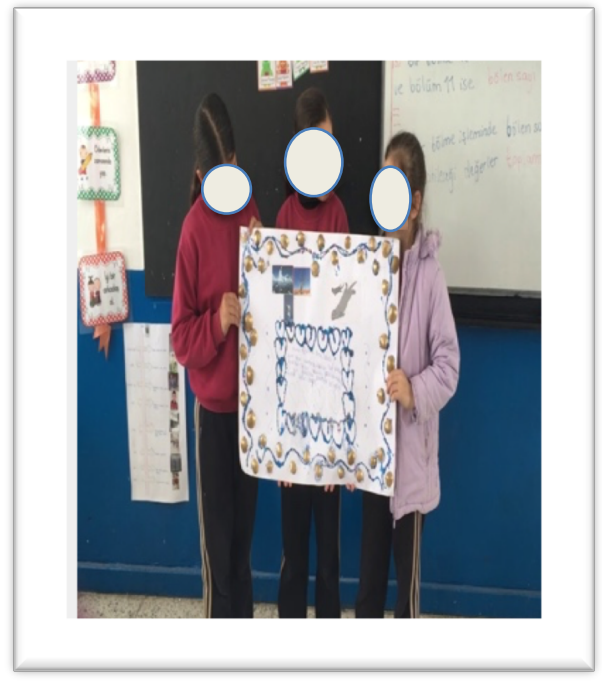

Fig. 3. Cooperative learning studies

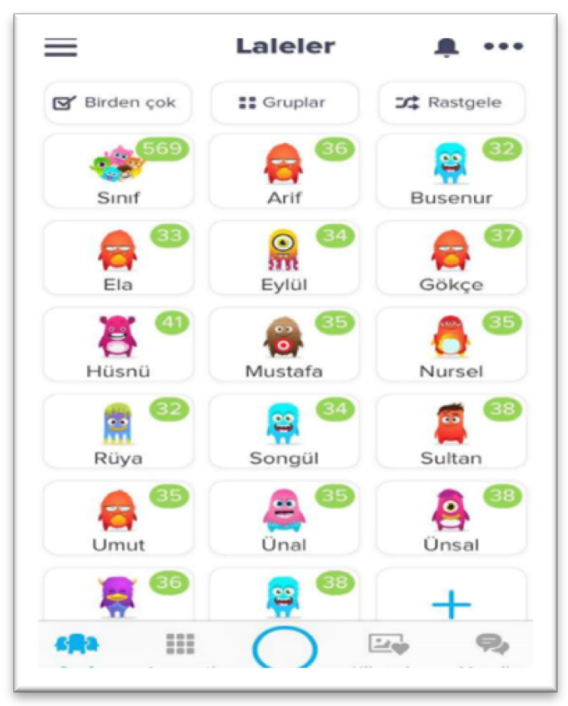

Fig. 5. Score distribution of the entire class 




Fig. 6. Project Studies

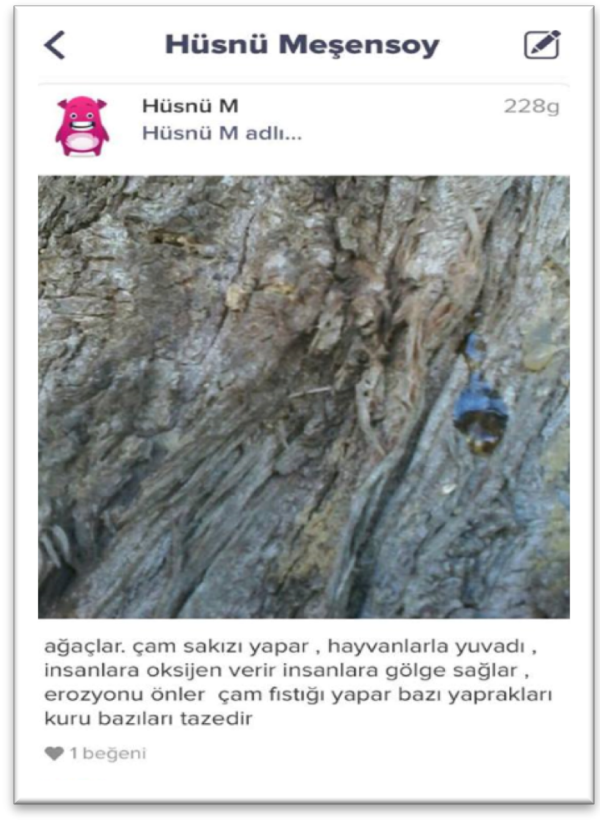

Fig. 7. Sharing in virtual class of the projects performed in nature

\subsection{Data Analysis}

Frequency, percentage, mean, standard deviation and Wilcoxon signed-rank test techniques were used in the analysis of quantitative data obtained from the research. The Wilcoxon signed-rank test was used with the purpose of testing the significance of the difference between the scores belonging to two related measurement sets. In addition, this test takes into consideration the direction and amount of the difference scores belonging to two related measurement sets. In the literature, it is stated that this test is frequently used in intra-group studies that are conducted with a limited number if test subjects in social sciences [32]. In this study, due to the low number of test subjects, pre-test - post-test measurements obtained from motivation scale for learning science were analysed with Wilcoxon signed-rank test techniques. The values obtained at the end of analysis were interpreted at 0.05 significance level.

Qualitative data of the study were obtained through face-to-face interviews with students and parents. In order to prevent data loss in the interviews, all conversations were recorded by the researcher. The recorded data were transcribed at the end of the interviews and analysed using the content analysis technique. One of the researchers analysed the transcribed texts and the other performed a double-check. Reliability calculation of qualitative data was conducted using the "reliability = agreement / (agreement + disagreement)" formula proposed by Miles and Huberman [33]. The concordance 
between two encoders was calculated as 80 percent. The categories created after coding were tabulated as frequencies. The obtained findings were supported by citations from the opinions of both students and parents. The students were indicated as (S) and parents were indicated as $(\mathrm{P})$ in the citations.

\section{Results}

The findings obtained from the study conducted with the purpose of determining the impact of gamification applications on the motivation of students for learning science and discovering the opinions of students and parents in regard to the usage of gamification applications are as follows.

\subsection{Comparison of motivation scores of students for learning science}

The Wilcoxon signed-rank test analysis technique was used in order to determine whether there was a significant increase in the motivation of students on leaning science at the end of gamification applications. The findings obtained from the pre-test and post-test scores on the motivations of the study group on learning science were tabulated and interpreted (see Table 1).

Table 1. Comparison of pre-test and post-test scores of students

\begin{tabular}{|c|c|c|c|c|c|c|}
\hline Dimensions & Posttest - Pretest & $\mathbf{N}$ & $\begin{array}{l}\text { Mean } \\
\text { Rank }\end{array}$ & $\begin{array}{l}\text { Sum of } \\
\text { Ranks }\end{array}$ & $\mathbf{z}$ & $\mathbf{p}$ \\
\hline $\begin{array}{l}\text { Motivation for do- } \\
\text { ing research }\end{array}$ & $\begin{array}{l}\text { Negative Ranks } \\
\text { Positive Ranks } \\
\text { Ties }\end{array}$ & $\begin{array}{l}2 \\
11 \\
3 \\
\end{array}$ & $\begin{array}{l}6.75 \\
7.05\end{array}$ & $\begin{array}{l}13.50 \\
77.50\end{array}$ & $-2.24^{*}$ & .025 \\
\hline $\begin{array}{l}\text { Motivation for per- } \\
\text { formance }\end{array}$ & $\begin{array}{l}\text { Negative Ranks } \\
\text { Positive Ranks } \\
\text { Ties }\end{array}$ & $\begin{array}{l}4 \\
11 \\
1 \\
\end{array}$ & $\begin{array}{l}6.00 \\
8.73\end{array}$ & $\begin{array}{l}24.00 \\
96.00\end{array}$ & $-2.05^{*}$ & .040 \\
\hline $\begin{array}{l}\text { Motivation for } \\
\text { communication }\end{array}$ & $\begin{array}{l}\text { Negative Ranks } \\
\text { Positive Ranks } \\
\text { Ties }\end{array}$ & $\begin{array}{l}3 \\
10 \\
3 \\
\end{array}$ & $\begin{array}{l}5.33 \\
7.50\end{array}$ & $\begin{array}{l}16.00 \\
75.00\end{array}$ & $-2.07 *$ & .038 \\
\hline $\begin{array}{l}\text { Motivation for co- } \\
\text { operative work }\end{array}$ & $\begin{array}{l}\text { Negative Ranks } \\
\text { Positive Ranks } \\
\text { Ties }\end{array}$ & $\begin{array}{l}3 \\
11 \\
2 \\
\end{array}$ & $\begin{array}{l}6.83 \\
7.68\end{array}$ & $\begin{array}{l}20.50 \\
84.50\end{array}$ & $-2.02 *$ & .043 \\
\hline $\begin{array}{l}\text { Motivation for par- } \\
\text { ticipation }\end{array}$ & $\begin{array}{l}\text { Negative Ranks } \\
\text { Positive Ranks } \\
\text { Ties }\end{array}$ & $\begin{array}{l}5 \\
7 \\
4 \\
\end{array}$ & $\begin{array}{l}4.60 \\
7.86\end{array}$ & $\begin{array}{l}23.00 \\
55.00\end{array}$ & $-1.26^{*}$ & .206 \\
\hline
\end{tabular}

* Based on negative ranks

The Wilcoxon signed-rank test results in regard to the significant differences between the motivation for learning science of students before and after the application are given in Table 1. Analysis results show that there is significant difference between the scores obtained from the motivation scale for learning science by the 4th grade students participating in the study before and after the test. It has been determined that there is a significant difference between the pre-test and post-test scores obtained by the students from the "motivation for doing research" dimension $(\mathrm{z}=-2.24, \mathrm{p}<.05)$, "motivation for performance" dimension $(z=-2.05, p<.05)$, "motivation for communication" 
dimension $(\mathrm{z}=-2.07, \mathrm{p}<.05)$ and "motivation for cooperative study" dimension $(\mathrm{z}=$ $2.02, \mathrm{p}<.05)$. Considering the mean rank and sum of ranks of the difference scores, it is seen that this difference is in favour of the positive ranks, indicating the post-test score. However, no significant difference was found in the motivation levels of students in terms of participation ( $\mathrm{z}=-1.26, \mathrm{p}>.05)$. In this context, it can be claimed that students are always willing to participate in science education, but that their motivation for doing research, communication and cooperative study increased positively after the test. The findings obtained from the study displayed that gamification applications are generally effective in increasing the motivation of students for learning science.

\subsection{Opinions of students in regard to gamification applications in science education}

Face-to-face interviews were held with students participating in the study in order to determine their emotions and opinions in regard to the usage of gamification applications in science education. During the interviews, students were asked such questions as "Did you like the science education classes?", "Were class activities nice?", "What did you learn in this class?", and "What do you think about this course?" The satisfaction status of students in regard to the application is given in Table 2.

Table 2. Satisfaction of students in regard to gamification applications in science education

\begin{tabular}{|c|l|c|}
\hline \multicolumn{1}{|c|}{ Themes } & \multicolumn{1}{c|}{ Codes } & f \\
\hline \multirow{3}{*}{ Satisfaction with science education classes } & Satisfied & 15 \\
\cline { 2 - 3 } & Indecisive & 1 \\
\cline { 2 - 3 } & Unsatisfied & - \\
\hline
\end{tabular}

As can be seen in Table 2, a majority of students expressed their satisfaction with the science education that incorporated gamification applications. From the data obtained in the research, it was determined that only one student was indecisive about the science education that employed gamification applications. Some of the opinions of students are given below:

(S9): "I wish our other courses were like this."

(S11): "Our classes were very nice."

(S3): "I would like to take this course again."

(S5): "I am sad this course is over."

(S12): "We always did things in the class. My teacher gave me tasks, but sometimes I was bored and did not want to do them."

The findings obtained from the study reveal that a majority of students were satisfied with the application and participated with pleasure. However, only student S12 showed an indecisive attitude towards the applications in which he/she participated. It is believed that S12 showed an indecisive attitude, as he/she did not want to do the tasks that were given in the class environment. The opinions of students in regard to science education that used gamification applications are given in Table 3. 
Table 3. Opinions of students in regard to the effectiveness of gamification applications in science education

\begin{tabular}{|l|l|c|}
\hline \multicolumn{1}{|c|}{ Themes } & \multicolumn{1}{|c|}{ Codes } & \multicolumn{1}{|c|}{ f } \\
\hline \multirow{4}{*}{ Intra-class communication } & Student-student communication & \multicolumn{1}{|c|}{8} \\
\cline { 2 - 3 } & Student-teacher communication & 6 \\
\cline { 2 - 3 } & Valuing & 4 \\
\cline { 2 - 3 } & Ease of learning & 1 \\
\cline { 2 - 3 } & A democratic environment & 13 \\
\hline \multirow{5}{*}{ Motivation } & Fun & 11 \\
\cline { 2 - 3 } & Curiosity & 7 \\
\cline { 2 - 3 } & Willingness & 5 \\
\cline { 2 - 3 } & Attractive & 2 \\
\cline { 2 - 3 } & A different application & \\
\hline
\end{tabular}

The opinions of students in regard to gamification applications are classified under two different themes titled "intra-class interaction" and "motivation". A majority of students stated that gamification applications realised in science education increased intra-class interaction. Students also stated that their communication with classmates was positively affected at the end of the gamification applications $(f=14)$. Some students, on the other hand, stated that gamification applications improved their communication with their teacher $(\mathrm{f}=8)$, whereas others claimed that they performed studies with their teammates during application and that teammates supported and valued each other $(\mathrm{f}=6)$. Some students stated that gamification applications provided convenience in learning topics $(\mathrm{f}=4)$. One student claimed that decisions were taken with the entire class in the applications in which they participated and that a democratic environment was created $(\mathrm{f}=1)$. Some of the opinions of students are given below:

(S15): "It was fun to name our teams with our friends."

(S4): "Working with my friends made me very happy."

(S10): "My teacher never got angry when I wanted to ask something."

(S7): "Sometimes we helped each other with my friends. It was nice to help each other with my friends. I love my teammates."

(S6): "Doing homework with my friends prevented me from forgetting the topics."

(S2): "When I gave wrong answers to questions, first my friends and then my teacher helped me correct it."

(S8): "Leaving the classroom during class, taking photographs and sharing them in ClassDojo ensured that I learn topics more easily. For example, after I saw the tree roots, it was easier for me to remember that tree roots prevented landslides."

Gamification applications positively affected the motivation of students for class. Most of the students expressed that the applications in which they participated were fun $(\mathrm{f}=13)$ and stated that they were curious about the class $(\mathrm{f}=11)$. Students also expressed that they participated in the classes willingly and gladly $(\mathrm{f}=7)$ and explained that photographs shared in ClassDojo application were particularly interesting $(\mathrm{f}=5)$. Two students stated that the application was very different from other classes and emphasised that they loved this difference: 
(S16): "This class was nothing like other classes. For example, we never had teams in class before. We had not used ClassDojo either..."

(S3): "Sharing pictures in ClassDojo was fun."

(S9): "I wanted me and my teammates to take all the badges that our teacher gave in the class."

(S4): "I am no longer embarrassed to give answers when my teacher asks me questions."

(S11): "I was very glad that our teacher gave us rewards."

(S5): "We did with my friends what we were asked by our teacher by leaving the classroom. We covered topics as if we were playing games. I had lots of fun."

(S7): "I really enjoyed coming to class with my tablet and using our tablets in the class. I liked this class very much."

As can be seen in Table 3, students were satisfied with the gamification applications in which they participated. In addition, science education which employed gamification applications attracted the attention of students towards the class and motivated the students for learning. In this context, the findings obtained from the qualitative data support the quantitative findings obtained from the motivation scale for learning science.

\subsection{Opinions of parents in regard to the employment of gamification applications in science education}

In order to determine the opinions of parents in regard to the usage of gamification applications, face-to-face interviews were conducted both before and after the application. The semi-structured interview form prepared by the researchers for the parents consisted of two sections, namely before and after application. Before the application, parents were asked such questions as "Do you think that science education classes offered at schools are adequate?", "What are your expectations from science education classes?", "Are you knowledgeable about gamification applications?" At the end of the application, parents were asked the questions "What do you think of gamification applications?", "Are you satisfied with this application? Why?", "In your opinion, what are the strengths and weaknesses of gamification applications?", "Would you like it if your child participated in these applications in other classes as well?", "Do you consider taking part in these applications at other times, too?" Qualitative data obtained from the interviews were classified into themes and codes and frequency tables were created. Table 4 provides details on the opinions of parents in regard to the usage of gamification applications before and after the application. 
Table 4. Opinions of parents as regards usage of gamification applications

\begin{tabular}{|l|l|c|}
\hline \multicolumn{1}{|c|}{ Themes } & \multicolumn{1}{|c|}{ Codes } & \multicolumn{1}{|c|}{ f } \\
\hline \multirow{5}{*}{ Opinions before application } & $\begin{array}{l}\text { I am unaware of gamification } \\
\text { applications }\end{array}$ & 16 \\
\cline { 2 - 3 } & An untypical education & 8 \\
\cline { 2 - 3 } & It might be a waste of time & 5 \\
\cline { 2 - 3 } & It might be beneficial & \multicolumn{1}{|c|}{2} \\
\cline { 2 - 3 } & Worth trying & 16 \\
\hline \multirow{5}{*}{ Opinions after application } & Reparticipation & 14 \\
\cline { 2 - 3 } & A wonderful application & 14 \\
\cline { 2 - 3 } & It must also be used in other & 10 \\
\cline { 2 - 3 } & classes & 8 \\
\cline { 2 - 3 } & Effective communication & 6 \\
\cline { 2 - 3 } & Beneficial & 6 \\
\cline { 2 - 3 } & Effective feedback & 3 \\
\cline { 2 - 3 } & Motivating & \multicolumn{2}{|c|}{} \\
\cline { 2 - 3 } & Fun & \multicolumn{2}{|c|}{} \\
\hline
\end{tabular}

As can be seen in Table 4, before the application, the parents did not have any information about gamification applications $(\mathrm{f}=16)$. Some of the parents stated that gamification applications were different from the traditional system to which they are accustomed $(\mathrm{f}=8)$ and that it could be a waste of time and as these applications were untypical $(f=5)$. Some parents, unlike others, expressed that these applications could be more beneficial as they were different from traditional education $(\mathrm{f}=4)$ and they believed they could be worth trying $(\mathrm{f}=2)$. Some of the opinions of parents are given below:

(P6): "If the teacher does not lecture the children in the class and make them write down all the information in their notebooks, children cannot learn the topics of the class.”

(P2): "If the teacher does not lecture in the class, the children will not be able to learn. It will be a waste of time."

(P9): "The idea that children will learn by doing projects together does not seem very convincing to me. I think that the teacher should perform and be active in the classroom."

(P15): "I think that it will be beneficial if the children participate in different applications so that they can learn and like the class."

At the end of the application, face-to-face interviews were held with the parents again and their opinions were consulted on gamification applications also in which they also participated. As can be seen in Table 4, all parents stated that they were willing to participate in the gamification applications in the future. In addition, parents stated that gamification applications were wonderful $(\mathrm{f}=14)$ and that they were satisfied with this application. Parents also expressed that gamification applications should be used in other classes as well $(\mathrm{f}=14)$ so that they could maintain constant communication with the teacher $(\mathrm{f}=10)$. In particular, parents who complained that they could not visit the teacher at school as they worked said that they could easily communicate with the teacher through the ClassDojo application. Parents who found the gamification application beneficial $(\mathrm{f}=8)$ explained that they had the opportunity to follow the feedback 
in regard to the development of their children with the ClassDojo application $(f=6)$. A total of 6 parents stated that these applications motivated their children towards the class, whereas 3 parents claimed that the applications created a fun learning environment for their children. Some of the opinions of parents at the end of the application are given below:

(P8): "In the beginning, I had thought that such an application was not necessary. But now I realise that my son participated in the classes enthusiastically and had fun."

(P16): "Education was given effective, which was very different from the education system that children are accustomed to. I wish that other teachers also use this application in their classes."

(P14): "I had as much fun as my daughter. I had the chance to follow the activities that my daughter participated in in the science education classes every week."

(P7): "As I had to work during school hours, I never had the chance to see the teacher. With this application, I had the opportunity to see the teacher outside school hours."

(P5): "We performed an application outside the system to which we are accustomed. This application increased the willingness and interest of my son towards the class."

As can be seen in Table 4, the opinions of parents after the application in regard to the gamification applications developed in a positive direction. With gamification applications, students abandoned their passive listener approach in the classroom and assumed an active role in the learning process. In this context, parents expressed their satisfaction with the gamification applications and suggested that similar applications should be realised in other classes as well.

\section{Discussion and Conclusion}

The purpose of this study was to explore the impact of gamification applications on the motivations of students for learning science as well as to identify the opinions of students and parents on the application. In the research conducted on 4th grade primary school students and their parents, it was found that gamification applications positively increased the motivation of students for learning science. The results obtained from the study showed that there is significant increase in the motivation scores of students on learning science before and after application. It is believed that the increase in motivation of students towards doing research, performance, communication and cooperative studies in science education resulted from the effectiveness of the gamification applications. Sar1 and Altun [34] included gamification elements in teaching activities in their study and concluded that gamification elements increased the interest, motivation and willingness of the students to participate in the class. In this context, Sar1 and Altun [34] made some suggestions to researchers and teachers at the end of the study in regard to the effective use of gamification in classes. In their study, Ding, Kim and Orey [35] used gEchoLu, which is a gamified online discussion tool with the purpose of increasing student participation and motivation. At the end of the study, it was found that game elements such as badges, thumps-ups, progress bars and avatars used in gEchoLu 
encouraged student participation in online discussions. Likewise, Khan, Ahmad and Malik [36] conducted a study on secondary school science classes and concluded that digital game based learning applications positively affected student participation. In addition, Y1ldirım [37] integrated a gamification framework to curricula with the purpose of improving students' motivations, academic success and attitudes towards class and concluded that the applications had a positive impact on the students' academic success and attitude towards the class.

Sanmugam et al. [30], who defined gamification as a new approach in the education world, stated that understanding the connection between student success and gamification elements is important. Sanmugam et al. [30] conducted a study on 29 secondary school students who were taking a science class and determined that technology and game elements were effective in changing the viewpoints of students. Buckley and Doyle [38] stated that there are suggestions in the literature that gamified learning applications could increase student participation and improve learning. In their study which examined the impact of online gamified learning applications on the internal and external motivation of students, Buckley and Doyle [38] found that gamification applications had a significantly greater impact on intrinsically motivated students. Moreover, Buckleya and Doyle [38] concluded in their study that there was a positive correlation between intrinsic motivation and participation. In addition, Buckley and Doyle [38] concluded that gamified learning applications generally had a positive impact on the learning of students. Likewise, Tunga and İnceoğlu [39] studied the impact of using gamification in e-learning environments on the motivation of learners. The research findings showed that using gamification elements in e-learning environments had a positive impact on the motivation levels of students [39]. In this context, it can be claimed that the findings of the mentioned study are supportive of the findings obtained in this research.

The findings obtained from the research demonstrated that the students were satisfied with gamification applications. Students expressed that they had healthier communication with their friends and teacher in the classroom due to the use of gamification applications; they also stated that they had the chance to learn science education topics more easily on ClassDojo, which was designed with the purpose of creating a virtual class. In addition, students found the applications in which they participated enjoyable and interesting. Y1ldırım and Demir [40] found in their study that students had positive opinions towards gamification-based teaching programmes. Students stated that they were happy to participate in gamification-based teaching programmes, that they had fun, found themselves in a better and more permanent learning experience, that positive competition increased their success and the communication with their friends increased [40]. Likewise, in one of his studies, Burger [41] displayed that ClassDojo was a very motivating class management system for students. Burger [41] stated that students and teachers thought that ClassDojo affected student achievement due to the increase in student participation. Likewise, the study developed by Chiarelli, Szabo and Williams [42] detected that ClassDojo had a positive impact on student behaviours. In addition, it was stated that ClassDojo helped students become more informed about behavioural preferences. MacLean-Blevins [43] determined in the study using the ClassDojo application that the positive and self-regulatory behaviours of students increased, whereas 
negative behaviours decreased. In addition, it was found that a majority of the students were positive about the online system. In summary, researches display that gamification applications and ClassDojo increased the class participation and motivation of students and positively affected intra-class communication and student behaviours. The findings in the literature that are summarised above are supportive of the findings obtained from this study.

Another research result is that parents also had positive opinions about the gamification application at the end of the application. Parents who did not have any information about gamification applications before the applications found the activities beneficial and effective at the end of the application. Parents especially stated that they had the opportunity to communicate effectively with the teachers and explained that they could follow the development level of their children closely. In addition, parents expressed that gamification applications motivated their children towards the class. In this context, the results obtained from the opinions of parents in regard to the application are consistent with the opinions of their children. Bicen and Kocakoyun [44] concluded in their study which used ClassDojo, an intra-class communication application, that students and parents had positive opinions on ClassDojo applications. Students stated that they felt excited about the ClassDojo application, while parents stated that the ClassDojo application improved the behaviours of children positively and was a motivating and enjoyable mobile application [44]. Likewise, Muntean [45] expressed that gamification helped increase the motivation of students towards learning and explained that with the help of positive feedback, students were more encouraged towards learning. Moreover, Hong and Masood [26] compared the traditional teaching method and gamification teaching method and found out that the gamification method had greater potential for increasing both the class participation and intrinsic motivation of students towards learning.

The obtained results demonstrate that gamification applications are effective in developing positive behaviours in the students. In addition, it was found that students and parents had positive opinions in regard to the gamification applications. In this study, gamification applications were only applied with 4 th grade primary students and the science education class that these students attended. At the end of the application, most of the parents who participated in the study recommended that gamification applications should also be used in different classes. In this context, it is suggested that gamification applications should be used at other levels of primary education and studies should be conducted to explore its impact in other classes. Besides, it is recommended that researchers should take into account the conclusions of this study in their future research conducted on this purpose.

\section{References}

[1] Baeten, M., Struyven, K., \& Dochy, F. (2013). Student-centred teaching methods: Can they optimise students' approaches to learning in professional higher education? Studies in Educational Evaluation, 39, 14-22. https://doi.org/10.1016/j.stueduc.2012.11.001

[2] Elmas, R., \& Geban, Ö. (2012). Web 2.0 tools for 21st century teachers. International Online Journal of Educational Sciences, 4(1), 243-254. 
[3] Nemorin, S. (2017). Affective capture in digital school spaces and the modulation of student subjectivities. Emotion, Space and Society, 24, 11-18. https://doi.org/10.1016/j.emospa.2017.05.007

[4] Gençer, B.G., Gürbulak, N., \& Adıgüzel, T. (2014). Eğitimde yeni bir süreç: Ters-yüz sınıf sistemi. International Teacher Education Conference, 881-888.

[5] Osipov, I.V., Volinsky, A.A., \& Grishin, V.V. (2015). Gamification, virality and retention in educational online platform. (IJACSA) International Journal of Advanced Computer Science and Applications, 6(4), 11-18.

[6] Hamari, J., \& Koivistoa, J. (2015). Why do people use gamification services? International Journal of Information Management, 35, 419-431. https://doi.org/10.1016/j.ijinfomgt.2015.04.006

[7] Gökkaya, Z. (2014). Yetişkin eğitiminde yeni bir yaklaşım: Oyunlaştırma. Hasan Ali Yücel Eğitim Fakültesi Dergisi, 11-1(21), 71-84.

[8] Simões, J.M.A.P., Redondo, R.D., Vilas, A.F. (2015).Using gamification to improve participation in social learning environments. University of Vigo, Doctoral Thesis.

[9] Kapp, K.M. (2016). Choose your level: Using games and gamification to create personalized instruction. In M. Murphy, S. Redding, \& J. Twyman (Eds.), Handbook on personalized learning for states, districts, and schools (pp. 131-143). Philadelphia, PA: Temple University, Center on Innovations in Learning. Retrieved from: http://www.centeril.org/2016handbook/resources/Cover Kapp web.pdf

[10] Groh, F. (2012). Gamification: State of the art definition and utilization. Retrived from: http://hubscher.org/roland/courses/hf765/readings/Groh 2012.pdf

[11] Dicheva, D., Dichev C., Agre G., \& Angelova G. (2015). Gamification in education: A systematic mapping study. Educational Technology \& Society, 18(3), 75-88.

[12] Nedergård, D. (2016). Internal motivation in gamification. Retrived from: http://www.divaportal.org/smash/get/diva2:939900/FULLTEXT01.pdf

[13] Sailer, M., Hense, J., Mandl, H., Klevers, M. (2013). Psychological perspectives on motivation through gamification. Interaction Design and Architecture(s) Journal - IxD\&A, 19, 2837.

[14] Seixas, L.R., Gomes, A.S., \& Filho, I.J.M. (2016). Effectiveness of gamification in the engagement of students. Computers in Human Behavior, 58, 48-63. https://doi.org/10.1016/j.chb.2015.11.021

[15] Su, C-H., Cheng \& C-H (2015). A mobile gamification learning system for improving the learning motivation and achievements. Journal of Computer Assisted Learning, 31, 268286. https://doi.org/10.1111/jcal.12088

[16] Al-Azawi, R., Al-Faliti, F., \& Al-Blushi, M. (2016). Educational gamification vs. game based learning: Comparative study. International Journal of Innovation, Management and Technology, 7(4), 132-136.

[17] Lister, M.C. (2015). Gamification: The effect on student motivation and performance at the post-secondary level. Issues and Trends in Educational Technology, 3(2), 1-22. https://doi.org/10.2458/azu itet v3i2 Lister

[18] Çağlar, Ş., \& Kocadere, S.A. (2015). Gamification in online learning environments. Eğitim Bilimleri ve Uygulama, 14 (27), 83-102.

[19] Güler, C., \& Güler, E. (2015). Gamification in online learning environment: The use of badge. Journal of Research in Education and Teaching, 4(3), 125-130.

[20] Akbaba, S. (2006). Eğitimde motivasyon. Kazım Karabekir Eğitim Fakültesi Dergisi, 13, 343-361. 
[21] Gürdoğan, A. (2012). Measurement levels of higher vocational school students motivation in education: The case of school in Ortaca. Muğla Üniversitesi Sosyal Bilimler Enstitüsü Dergisi, 28, 149-165.

[22] Uyulgan, M.A., \& Akkuzu, N. (2014). An overview of student teachers' academic intrinsic motivation. Educational Sciences: Theory \& Practice, 14(1), 24-32.

[23] Çolak, E., \& Cirık, İ. (2015). Analysis of motivational orientation of secondary school students. Elementary Education Online, 14(4), 1307-1326.

[24] Ryan, R.M., \& Deci, E.L. (2000). Intrinsic and extrinsic motivations: Classic definitions and new directions. Contemporary Educational Psychology, 25, 54-67. https://doi.org/10.1006/ceps.1999.1020

[25] Reiss, S. (2012). Intrinsic and extrinsic motivation. Teaching of Psychology, 00(0) 1-5. https://doi.org/10.1177/0098628312437704

[26] Hong, G.Y., \& Masood, M. (2014). Effects of gamification on lower secondary school students' motivation and engagement. International Scholarly and Scientific Research \& Innovation, 8(12), 3757- 3764.

[27] Erdoğdu, F., \& Karatas, F.O. (2016). Examining the effects of gamification on different variables in science education. 2016 Hoca Ahmet Yesevi Yılı Anısına Uluslararas1 Türk Dünyası Eğitim Bilimleri ve Sosyal Bilimler Kongresi.

[28] Sánchez-Martín, J., Cañada-Cañada, F., \& Dávila-Acedo, M.A. (2017). Just a game? Gamifying a general science class at university Collaborative and competitive work implications. Thinking Skills and Creativity, 26, 51-59. https://doi.org/10.1016/j.tsc.2017.05.003

[29] Mekler, E.D., Brühlmann, F., Opwis, K., \& Tuch, A.N. (2013). Do points, levels and leaderboards harm intrinsic motivation? An empirical analysis of common gamification elements. Gamification 2013: Proceedings of the First International Conference on Gameful Design, Research, and Applications. October 2-4, 2013 in Stratford, Ontario, Canada.

[30] Sanmugam, M.A.L., Abdullah, Z.B., Mohamed, H., Aris, B., Zaid, N.M., \& Suhadi, S.B.M. (2016). The affiliation between student achievement and elements of gamification in learning science. 4th International Conference on Information and Communication Technology (ICoICT), 25-27 May 2016. https://doi.org/10.1109/ICoICT.2016.7571962

[31] Dede, Y., \& Yaman, S. (2008). A questionnaire for motivation toward science learning: A validity and reliability study. Necatibey Faculty of Education Electronic Journal of Science and Mathematics Education, 2(1), 19-37.

[32] Büyüköztürk, Ş. (2005). Sosyal bilimler için very analizi el kitabı. Ankara: Pegem A Yayıncilik.

[33] Miles, M.B., \& Huberman, A.M., (1994). Qualitative data analysis: An expanded sourcebook. (2nd Edition). Thousand Oaks, (Cal.): SAGE Publications.

[34] Sarı, A., \& Altun, T. (2016). Oyunlaştırma yöntemi ile işlenen bilgisayar derslerinin etkililiğine yönelik öğrenci görüşlerinin incelenmesi. Turkish Journal of Computer and Mathematics Education,7(3), 553-577. https://doi.org/10.16949/turkbilmat.277871

[35] Ding, L., Kim, C.M., \& Orey, M. (2017). Studies of student engagement in gamified online discussions. Computers \& Education, 115, 126-142. https://doi.org/10.1016/j.compedu.2017.06.016

[36] Khan, A., Ahmad, F.H., \& Malik, M.M. (2017). Use of digital game based learning and gamification in secondary school science: The effect on student engagement, learning and gender difference. Educ Inf Technol https://doi.org/10.1007/s10639-017-9622-1

[37] Yildirim, I. (2017). The effects of gamification-based teaching practices on student achievement and students' attitudes toward lessons. Internet and Higher Education, 33, 86-92. https://doi.org/10.1016/j.iheduc.2017.02.002 
[38] Buckleya, P., \& Doyle, E. (2014). Gamification and student motivation. Interactive Learning Environments https://doi.org/10.1080/10494820.2014.964263

[39] Tunga, Y., \& İnceoğlu, M.M. (2016). E-öğrenme ortamlarında oyunlaştırma yaklaşımı kullanımının öğrenenlerin motivasyon durumlarına katkısının incelenmesi. 10th International Computer and Instructional Technologies Symposium (ICITS), 16-18 May 2016, Rize, Turkey.

[40] Yıldırım, İ., \& Demir, S. (2016). Students' views about gamification based curriculum fot the lesson of "teaching principles and methods". Uluslararası Eğitim Programları ve Öğretim Çalışmaları Dergisi, 6(11), 85-101.

[41] Burger, M.S. (2015). The perception of the effectiveness of ClassDojo in middle school classrooms: A transcendental phenomenological study. School of Education, Doctor of Education. Liberty University. Retrived from: http://digitalcommons.liberty.edu/doctoral/1063/

[42] Chiarelli, M., Szabo, S., \& Williams, S. (2015).Using classdojo to help with classroom management during guided reading. Texas Journal of Literacy Education, 3(2), 81-88.

[43] MacLean-Blevins, A.O. (2013). Class DoJo: Supporting the art of student self-regulation. Rising Tide, 6, 1-20.

[44] Bicen, H., \& Kocakoyun, S. (2017). Classroom management through ClassDojo in gamification approach. J. Ponte, 73(8) https://doi.org/10.21506/j.ponte.2017.8.36

[45] Muntean, C.I. (2011). Raising engagement in e learning through gamification. The 6th International Conference on Virtual Learning ICVL, 323-329.

\section{Authors}

Cigdem Hursen works as an associate professor at Near East University. In October 2013, she was appointed to be the chairperson of the department of Social Sciences of Near East University, Atatürk Education Faculty. In the same year, she was also appointed as the chairperson of the department of Measurement and Evaluation.

Cizem Bas is a PhD student at Division of Curriculum and Instruction, Near East University. Also, she is a teacher at primary school.

Article submitted 22 May 2018. Resubmitted 13 June 2018. Final acceptance 13 June 2018. Final version published as submitted by the author. 